\title{
OGRIZOVIĆEV DIOKLECIJAN - REALNOST ILI FIKCIJA?
}

Nenad Cambi

Zoranićeva 4/II

HR 21000 Split

nenad.cambi@xnet.hr
UDK: 82.163.42-2Ogrizović, M. Izvorni znanstveni članak Ur.: 2021-08-23

Milan Ogrizović napisao je u povodu proslave 1600. obljetnice Milanskog edikta dramu Car Dioklecijan, koju je inscenirao u posebno napisanom epilogu Smrt cara Dioklecijana, izvedenom u Peristilu Dioklecijanove palače u Splitu 28. listopada 1913. godine. Glavni lik drame je car Dioklecijan, koji je u historijskim vrelima predstavljen kao nepomirljivi neprijatelj kršćanstva. Dokazujući tezu o velikom caru kao progonitelju kršćana, Ogrizović se referira i na neke historijski nepotvrđene događaje iz njegova života.

Autor članka pronalazi i kritički komentira niz sadržajnih i kronoloških nepodudarnosti između autentičnih historijskih vrela i sadržaja drame. Zaključuje da se Ogrizović postavio slobodno u odnosu na povijesne činjenice, držeći da je kao književnik imao pravo na svoju umjetničku slobodu.

Ključne riječi: Milan Ogrizović, drama, car Dioklecijan, kršćanstvo

Milan Ogrizović (1877. - 1923.), Senjanin rođenjem, Zagrepčanin karijerom, sahranjen također u Zagrebu, istaknuti je hrvatski književnik i kazališni djelatnik.

Još prije Prvog svjetskog rata na kazališnu pozornicu stavio je Dioklecijana, rimskog vojnika, zapovjednika i cara reformatora, utemeljitelja tetrarhijskog sustava kojim se nadao da će zaustaviti krizu Rimskog carstva, već urušenoga brojnim nasilnim promjenama na tronu, vojnim prevratima i sl. Dioklecijan je svojim potezima i reformama izazvao brojne prijepore za vrijeme vlasti, a i poslije smrti. Sve do današnjih dana postoje kontradiktorna mišljenja pri vrednovanju njegove osobe te osobnosti vlasti i uprave, unatoč tomu što su brojni vrsni povjesničari o njemu osobno, pa i o njegovoj vlasti, imali pozitivno mišljenje. Tako ga, na primjer, Edward Gibbon hvali riječima: "Poput Augusta, Dioklecijana možemo smatrati utemeljiteljem novog carstva. Poput posvojenog Cezarova sina, odlikovao se prije državničkim nego 
ratničkim vrlinama; nijedan od te dvojice vladara nije pribjegavao nasilju, kad god je cilj mogao ostvariti politikom."1

Dioklecijan je kao neumorni reformator zavrijedio i Mommsenove riječi, a to nisu bilo čije riječi, da je bio državnički genij prvoga reda. ${ }^{2}$ Theodor Mommsen se, naime, veoma pozitivno izrazio o njegovom političkom profilu. Međutim, stigma progona kršćana pratila ga je kao sjenka od koje nije mogao pobjeći. Prilike u kojima je živio i pokušavao spasiti posrnulo Rimsko carstvo ne ekskulpiraju ga za nepravdu koju je počinio manihejcima i kršćanima. Međutim, krive su bile više prilike u kojima je živio nego mržnja prema novoj vjeri. Da je bio socijalno osjetljiv, svjedoči preambula njegova edikta o maksimiranju cijena koji je donio u najboljoj vjeri da će olakšati život puku, ali je u realnosti postigao suprotni učinak. Dioklecijanov život i carevanje su u popularnoj kulturi, ali i u znanosti nezasluženo skrenuli na sporedni kolosijek.

S druge strane, činjenica što je Dioklecijan podrijetlom iz Dalmacije, iz Salone ili Dokleje uvijek je kroz stoljeća golicala intelektualnu maštu ljudi iz naših krajeva. ${ }^{3}$ Mali narod kao Hrvati, smješten na nešto širem prostoru antičke Dalmacije, željan je posjedovanja velikih ličnosti pa čak kad ih, kao u ovom slučaju, prati stigma progonitelja kršćana. Milan Ogrizović je književnik koji je Dioklecijana izveo i na pozornicu, zapravo na sâm carev Peristil na kojem se ovaj pojavljivao za vrijeme povijesnih događanja, audijencija i drugih različitih protokolarnih svečanosti. To je autentični prostor da autentičniji ne može biti. Taj je javni dio carske rezidencije nedvojbeno najatraktivnija lokacija za suvremeni ambijentalni teatar. ${ }^{4}$ Ogrizoviću je kao teatarskom čovjeku bilo zanimljivo smjestiti radnju upravo na takvo mjesto na kojem je protagonist doživljavao počasti kao imperator senior i posljednje dane svoga života. Autoru je uspjelo godine 1913., u povodom obilježavanja 1600. obljetnice tzv. Milanskog edikta inscenirati posebno napisani dodatak Smrt cara Dioklecijana. Vjerojatno je upravo povijesni povod bio poticaj da Dioklecijana pisac oboji kao nepomirljivog neprijatelja kršćanstva. Predstavu je režirao i interpretirao glavnu ulogu veliki hrvatsko-slovenski glumac i redatelj Hinko Nučić.

${ }^{1}$ E. GIBBON, 2009, 362.

${ }^{2}$ A. DEMANDT, 2007, 75.

${ }^{3}$ O jednoj ili drugoj mogućnosti Dioklecijanova podrijetla v. N. CAMBI, 2016, 27-33. Jedini izvor koji preciznije upućuje na podrijetlo je dosta nepouzdano djelo Epitome de Caesaribus $39,1$.

${ }^{4}$ Već odavno se u Splitu začela ideja ljetnih spektakla, a Peristil je uvijek bio u središtu, osobito pogodan za povijesne predstave (opere Aida, Nabucco, Don Carlos) i grčki teatar (Eshil, Sofoklo i Euripid). Šteta što se nije ustrajalo na takvom izboru kao okosnici repertoara. 


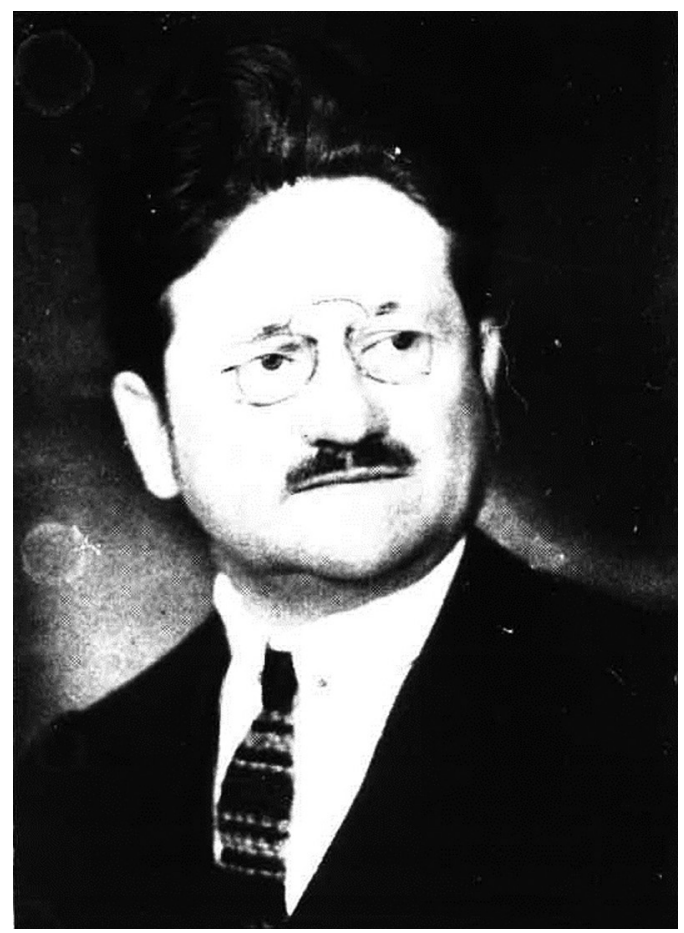

Sl. 1. Milan Ogrizović (1877. - 1923.) (izvor: Gradski muzej Senj)
M. Ogrizović je zapravo napisao dva uratka o Dioklecijanu - jedan duži Car Dioklecijan, a drugi već spomenuti Smrt cara Dioklecijana. ${ }^{5}$ Potonji uradak je, prema mišljenju autora, manje logična i uspjelija verzija careva završetka jer nije izrasla na prethodnim zbivanjima. Ogrizović je očito bio u dilemi koja se nameće kod gotovo svih povijesnih tema: što od povijesne građe staviti u središte zbivanja, a što odbaciti i kako postići dramski vrhunac. Odlučio se za temu odnosa cara prema kršćanima: s jedne je strane Dioklecijan moćni vladar, a s druge je kršćanstvo kao nova i propulzivna religija. Sukob progonitelja i proganjanih je realističan te povijesno utemeljen, ali ipak prenaglašen.

Prvi dio radnje počinje zasjedanjem carskog vijeća u

Nikomediji, sazvanim da se zaustavi razvoj kršćanstva i da se ta vjera stavi izvan zakona. Ogrizović na scenu izvodi povijesno prisutne i neprisutne osobe; pogrešno izvođenje nenazočnih osoba na vijećanju nije mu bilo važno. Ovaj rad to ocjenjuje teatrološkom potrebom, a ne neznanjem. Tako na zasjedanju, na kojem se odlučuje o početku progona, u realnosti nisu nazočili Dioklecijanov suvladar Maksimijan, a ni svećenici (augures, haruspices i sl.), ali je time dobio na religijskoj i političkoj uvjerljivosti i težini. Svećenici i suvladari su pouzdano bili konzultirani, ali su izočni pri odlučivanju.

Tko je sve mogao sudjelovati na jednom takvom vijećanju, nije znano, ali se smije nagađati. Pouzdano je inicijator svega bio Galerije koji je na vijećanju i vodio glavnu riječ. Osim njega, nazočiti je mogao još samo

${ }^{5}$ Nakon prvog izdanja Ogrizovićevi tekstovi su tiskani i u knjizi Ivana Boškovića, Car na pozornici - Dramska hrestomatija o caru Dioklecijanu, Zagreb, 2012. Bošković nije ulazio u povijesnu autentičnost (I. BOŠKOVIĆ, 2012, 27-134). 
Konstantin, tada vojni zapovjednik na "naukovanju" kod Dioklecijana, ali i to je upitno zbog otvorene netrpeljivosti između njega i Galerija. ${ }^{6}$ Konstantinov status je tada bio svladavanje ratne vještine i kušnja u lojalnosti. ${ }^{7}$ Maksimijan ne sudjeluje u provođenju edikta, ali je nedvojbeno bio konzultiran. Ogrizović na scenu dovodi čak i rimskog martira Sebastijana ${ }^{8}$ i pogrešno mu daje ulogu zapovjednika carske straže u Nikomediji. S time se nije zadovoljio te je uveo i salonitanske martire, vojnike Antiohijana, Gajana i Telija. I jedno i drugo je kronološka i tvarna pogreška. Sebastijan je navodno ubijen godine 288. u Rimu, ali tada još nije bilo progona. Sebastijan s Dioklecijanom nije imao nikakve veze. Valja s druge strane naglasiti da na Zapadu opći progoni počinju tek 304. godine. Ovo uvođenje navedenih likova treba smatrati Ogrizovićevom umjetničkom slobodom, a ne slabim poznavanjem kronologije. S druge strane, progoni na Zapadu bili su mnogo blaži nego na Istoku i Sebastijan je po svoj prilici Maksimijanova, a ne Dioklecijanova žrtva (ako se tako smije kazati), ali naravno ne izravna. Ni Sebastijan ni spomenuti vojnici nemaju veze $\mathrm{s}$ Nikomedijom. ${ }^{9}$ Unatoč autorskoj slobodi, ipak valja postaviti pitanje kakvog smisla ima upetljati, doduše povijesne, ali ipak ličnosti koje s realnošću zbivanja nisu imale nikakvu vezu? Zar ne bi bilo bolje izmisliti imena s istom ulogom? Osim Galerija i dakako Dioklecijana, moguće je da je na vijeću u Nikomediji bio i Maksimin Daja iako tada još nije cezar.

Drugi čin drame događa se u Saloni. Autorska sloboda također je dopustila Ogrizoviću da u Saloni na suđenju salonitanskim martirima dade i Dioklecijanu aktivnu ulogu - nalogodavca, ali i sudionika u procesu. On se poslužio Bulićevom nedokazanom i, bolje rečeno, nedokazivom tezom da se car na povratku iz Rima preko Ravenne spustio uz istarsku obalu do Salone da bi se osvjedočio u napredak izgradnje Palače u Splitu. ${ }^{10}$ Tom prigodom je tobože

${ }^{6} \mathrm{Za}$ doba tetrarhije posebno je važan Laktancijev spis De mortibus persecutorum (dalje Laktancije $D M P$ ). Korišteno kritičko izdanje toga djela pripremio je J. L. CREED, 1989. Laktancije $D M P$ 11, 3 izričito navodi da su dva vladara (Dioklecijan i Galerije) čitavu zimu vijećala, a u isto doba se tražilo mišljenje prijatelja (nedvojbeno careva i dužnosnika).

${ }^{7}$ Laktancije $D M P, 18,10$.

${ }^{8}$ Sebastijan je podrijetlom iz Galije (?), centurion u Rimu, gdje je i ubijen strelicama. Svečanost mu je 26. siječnja. Usp. Velika knjiga svetaca, 2011, 26.

${ }^{9}$ Među njima iz nama nepoznatih razloga nije spomenut i četvrti njihov sudrug u navodnom martiriju - Paulinijan. Ova četiri martira bijahu pokopana u Saloni na cemeteriju Kapljuč, zajedno sa svećenikom Asterijem. O njihovom groblju usp. E. DYGGVE, 1951, 71-87, sl. IV, 2, IV, 12 b, IV, 26, 27.

${ }^{10}$ F. BULIĆ, 1984, 71-85. Ovdje treba nadodati da plovni put iz Ravenne u Salonu ne vodi uz istarsku obalu, već kroz tjesnac između Cresa i Lošinja kod Osora (Apsorus). 


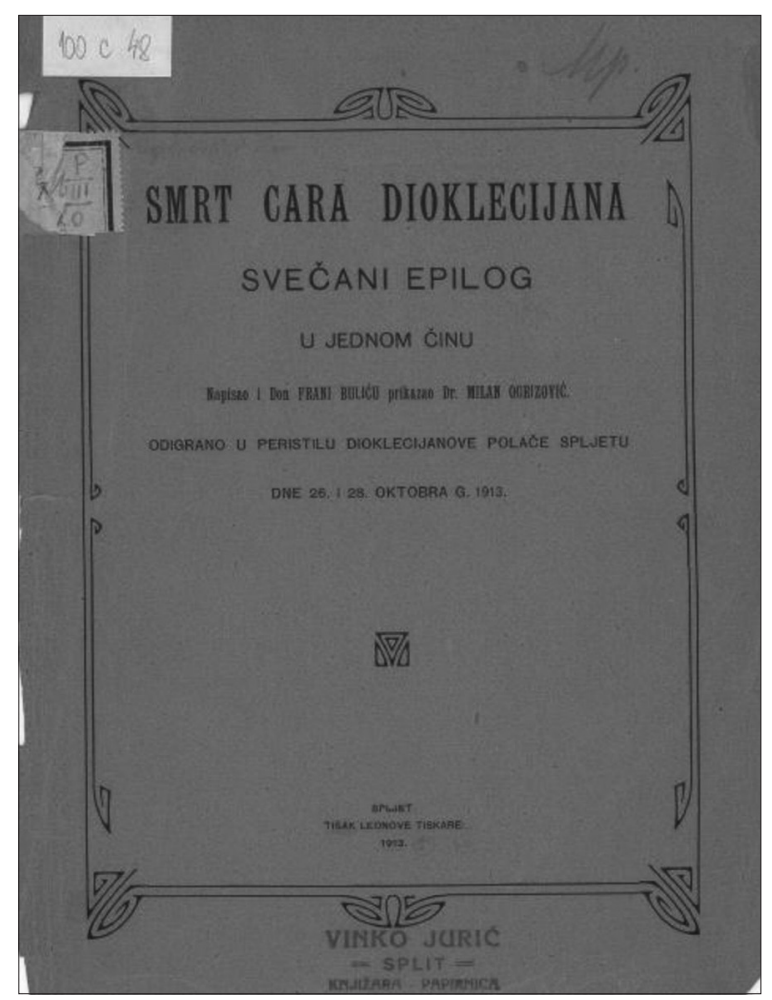

S1. 2. Naslovnica knjižice Smrt cara Dioklecijana tiskana u povodu premijere drame (izvor: Arheološki muzej Split) lako mogao "skoknuti" i do Salone te sudjelovati u suđenju Dujmu (Domnio) i drugima. Bulićevu tezu s oprezom je podupro samo Rapanić. ${ }^{11}$ Međutim, to se ni kronološki ne preklapa jer je Dioklecijan putovao nošen u nosiljci krajem godine 303. i stigao $u$ gotovo komatoznom stanju u Nikomediju, gdje je pobolijevao čitavu godinu do malo prije abdikacije. ${ }^{12}$ Uobičajeni put iz Italije na Istok vodio je cestama uz južne obalu Dunava. ${ }^{13}$ Kronološki progoni $u$ Saloni su se odvijali od kraja ožujka i najkasnije do kraja kolovoza $304 .{ }^{14}$ U nikomedijskoj palači početkom 304. već su svi ukućani mislili da je Dioklecijan mrtav i da se čeka samo dolazak odsutnog Galerija da bi se obznanila smrt. To ipak nije bila istina. Car se oporavio i na proljeće 305. konačno odlučio abdicirati. Čitavo je vrijeme Dioklecijan inzistirao na povlačenju unatoč Maksimijanovim nagovorima da zajednički

${ }^{11}$ Ž. RAPANIĆ, 2007, 64-65, osobito bilj. 106.

${ }^{12}$ Laktancije $D M P 17,3-4$.

${ }^{13}$ Pitanje je na što misli Laktancije DMP 17, 4 (per circuitum ripae Istricae Nicomedian venit). Ister je latinski hidronim za Dunav i to je najduži dio trase pa se zato i navodi. Zašto bi Laktancije spominjao istočnu obalom Jadrana, kad je pomorski put do Nikomedije uz mnoge druge opasnosti i znatno duži i opasniji (na primjer rt Matapan i Egejsko more), bez obzira na moguće zaustavljanje u Saloni.

${ }^{14}$ Posljednji mučenik je Anastazije kojemu je nadnevak u splitskoj crkvi 26. kolovoza. Nije, dakako, pouzdano, ali je tradicija moguća. Možda je samo pitanje je li to datum pogubljenja ili translacije. 
još nastave upravljati. ${ }^{15}$ To je pisac drame ispravno uočio, ali je neispravno upleo i Maksimijana u svečanost abdikacije u Nikomediji jer je on pouzdano bio na Zapadu. Maksimijan je zajedničku odluku bespogovorno i poslušno proveo u svome glavnom gradu (Mediolanum).

Postoji još jedna zamjerka autoru vezana uz povijesnu egzaktnost, nešto drugačijeg karaktera. Naime, u pitanju je sâm proces suđenja martirima i žrtvama, kao i dodijeljene kazne. Nije proces rimskim građanima predviđao mučenje i iznuđivanje žrtve za cara. Istina je da se tražila minimalna lojalnost (prinošenje zrnca tamjana ili malo žita i vina na plamteći žrtvenik), ali u tome nije bilo prinude. Sud traži slobodno odlučivanje, ali i zakonsku kaznu. Žrtvovanje su Rimljani smatrali izrazom lojalnosti državi i caru kao božanskoj emanaciji. ${ }^{16}$ Kršćani, naprotiv, žrtvovanje doživljavaju kao priznanje cara bogom, što je bitna koncepcijska razlika. Za kršćane postoji samo jedan jedini i nedjeljivi Bog unatoč trojstvu. Ispravni kršćani ne bježe od kazne; ona je za njih trijumf vjere. Odsijecanje glave kazna je rimskim građanima, a nerimskim pripadaju znatno teže i okrutnije kazne: utapanje, davljenje, križ ili pak gađanje kopljima za stup vezanoga osuđenika, bacanje pred zvijeri i dr. U Saloni su svi martiri (uglavnom su i dobro epigrafski i arheološki dokumentirani) bili dekapitirani u amfiteatru, osim Anastazija, koji je očito bio robovskog podrijetla pa je udavljen u Salonitanskom zaljevu i potom bio čašćen u velebnoj bazilici na Marusincu. ${ }^{17}$ Uz Domnija, i Anastazije se i danas štuje u splitskoj katedrali na dan 26. kolovoza. Kult mu je iznimno visok. Dakle, ono što se u drami izriče kao kazna (ad bestias) je netočnost, a pogotovo da je to tražio sâm Dioklecijan. Car nedvojbeno zna kakve kazne pripadaju osuđenima prema njihovom statusu. U Laktancijevom spisu stoji, doduše, da je Galerije imao izvježbane medvjede za kažnjavanje kršćana, što je nedvojbena potvrda postojanja takvih kazni, ali ne za rimske građane. ${ }^{18}$

Još je jedna kronološka nesklapnost u posve beznačajnom kontekstu Konstantinova kršćanstva i spomen njegove majke koja, tobože, već na samom

${ }^{15}$ Laktancije DMP 18, 7 spominje korespondenciju s Maksimijanom, a Galerije još informira da potonji osnažuje vojsku. Od augusta Maksimijana i cezara Konstancija I. tražilo se da postupaju prema već donesenim odlukama u Nikomediji (Laktancije DMP 15, 6-7. Očito je da je Galerije shvatio da je došao trenutak odluke pa stupa u akciju i pritišče Dioklecijana da donese odluku o abdikaciji.

${ }^{16}$ O progonima usp. N. CAMBI, 2016, 74-84, 95-101.

${ }^{17}$ E. DYGGVE, 1951, 102, sl. V, 12 A; F. BULIĆ, 1984, 336-337. Dygvve datum smrti Anastazija (vjerojatno pogrešno) stavlja na dan 26. ožujka, a Bulić misli da je dan teško odrediv. Usp. i bilj. 14.

${ }^{18}$ Laktancije DMP 21, 5-7. 


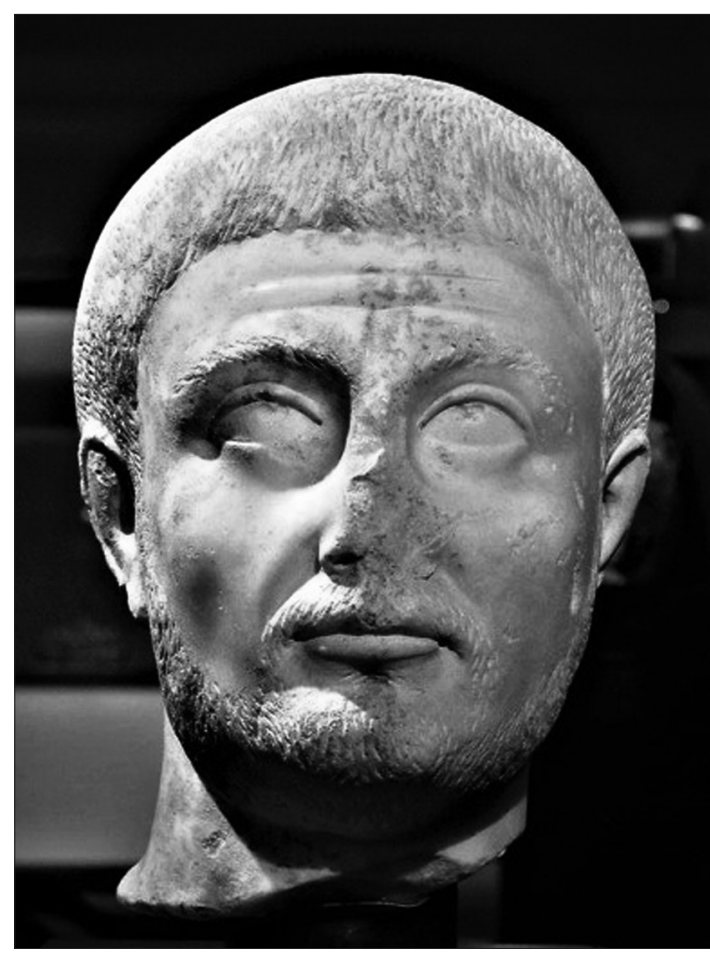

S1. 3. Salona (Solin), portret muškarca, vjerojatno Dioklecijan

(izvor: Universalmuseum Joanneum, Graz)

početku sinovljeve vlasti otkriva ostatke križa na Golgoti. ${ }^{19}$ Međutim, to se dogodilo tek znatno kasnije, godine 326. kad ona boravi na Istoku. "Otkrivene" relikvije Helena je pohranila u Rimu u crkvi Santa Croce in Gerusaleme. ${ }^{20}$ Čudno je što autor takvu kronološku nepodudarnost koristi kad mu je za radnju posve nepotrebno. Istina je, doduše, da je kršćanstvo bilo prisutno u obitelji Konstancija I., jer mu se jedna kći (Konstantinova polusestra) zvala Anastazija (od anastasis - uskrsnuće). Majka joj je Theodora, a ne Helena.

Ogrizović Dioklecijana dramatski suočava s kršćanskim trijumfom. Kršćani mu likujući stižu na vrata palače skandirajući starozavjetni i aramejski mene, tekel, fares (što je kronološki i religijski besmisao). ${ }^{21}$ Razjaren car se naoružava i želi sve posmicati, a čak ga ni žena Priska ni kći Valerija ne uspijevaju odvratiti od ludosti i tlapnje. Priviđaju mu se solinski (trebalo bi salonitanski) martiri na čelu s Dujmom (trebalo bi Domnijem), biskupom i svecem. Autor njih uvodi kao deus ex machina (10 godina poslije njihove smrti). Bez njih radnja ne bi mogla završiti kršćanskim trijumfom, što je prikladno s obzirom na povod pisanja i prikazivanja drame: obilježavanje 1600. obljetnice Milanskog edikta, ali je kronološki netočna. Usporedba s trajanjem trijumfa i progona je fascinantna. Kršćanstvo je još vitalno i dominantno unatoč shizmama. Progoni su trajali samo

\footnotetext{
${ }^{19}$ Naprotiv, Helena boravi u Palestini u potrazi za ostatcima Kristova stradanja od 326/327. pa do oko 329. To je već sam kraj Konstantinove vlasti.

${ }^{20} \mathrm{H}$. BRANDENBURG, 2004, 104-108.

${ }^{21}$ Citat je iz proroka Daniela 5:30-31 koji znači bliže ti se dani (smrt), što se odnosi na kralja Belshazara iz VI. st. prije Kr.
} 
nekoliko godina, a Edikt je godine 2013. obilježio čak 1700. obljetnicu donošenja i kontinuiteta. Dioklecijan je umro, a nova vjera, unatoč njegovim persekucijama, još traje. Međutim, valja istaknuti da Dioklecijan nije umro od žalosti zbog pobjede kršćanstva, već zbog tragedije svoje obitelji. ${ }^{22}$ Mogao je Ogrizović i na Dioklecijanovoj sudbini izgraditi tragičnu priču, ljudski veličanstvenu i istinski patetičnu.

Dioklecijanovo tvrdoglavo nastavljanje "poganske" vjere i uvjerenost u pobjedu Jupiterova orla ipak je dosta logična bez obzira na to što on sam prema Laktanciju, kojega je Ogrizović poznavao, nije bio toliko žestoki pobornik sveobuhvatnih progona jer je bio protiv bespotrebnog prolijevanja krvi, osobito vojničke, koja je uvijek i jest deficitarna. Međutim, on nije, kao što Ogrizović navodi, razočarano bjesnio jer su njegove najbliže Priska i Valerija postale kršćanke. Ovaj moment je zasnovan na jednom nepotvrđenom navodu. Naime, Laktancije spominje da je i ženu i kćer Dioklecijan okaljao žrtvom. ${ }^{23}$ Činjenica jest da Laktancije jedino njih dvije pozitivno opisuje, ali ni jednom riječi ne spominje njihovo kršćanstvo. Pretpostavka je, stoga, nedokaziva. Može se pretpostaviti da bi kršćanski pisac mogao iskoristiti njihovo kršćanstvo u propagandne svrhe, ali ipak je ostavio tračak sumnje.

Ni Galerije nije prešao na kršćanstvo kad je godine 311. izdao Edikt o slobodi kršćanske vjere ${ }^{24}$ koji je poslužio kao podloga za kasniji Konstantinov i Licinijev (Milansko-nikomedijski). ${ }^{25}$ Galerije u ediktu kršćanstvo naziva ludošću, ali, ako je kršćani hoće, neka je imaju, samo ih obvezuje na odanost rimskom caru i državi. To je bit međusobnih kršćansko-poganskih odnosa koji je prethodno urodio tragičnim nerazumijevanjem. Konstantinov edikt također stavlja naglasak na lojalnost caru. Politički obojeni edikti su izraz tolerancije, a ne prelazak čitavog naroda na novu vjeru, na način cuius regio illius religio, što znači: obvezni prelazak na vjeru suverena.

Ni za Konstantina se ne može reći da je odmah poslije Edikta kršten. Ako uopće i jest, to se zbilo tek na samrtnoj postelji, kako izravno navodi njegov savjetnik Euzebije, nikomedijski biskup, ali arijanac. ${ }^{26}$ Konstantin je očito kalkulirao. Za Licinija se pak zna da je politički bio kolebljiv i da je želio suziti mogućnost utjecaja kršćana na njegovom dvoru u Bizantu, kasnijem Konstantinopolu. Što se Maksimina Daje tiče, nema nikakve dvojbe da je bio

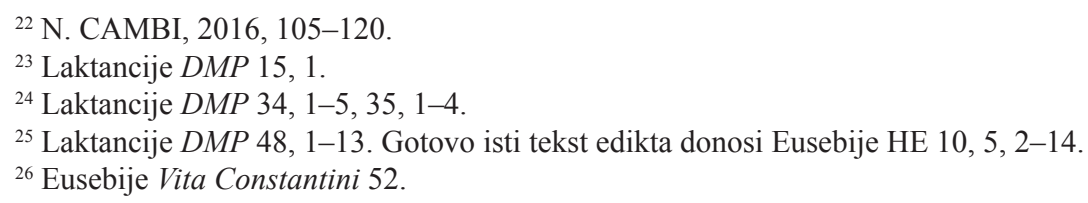


žestoki poganin. Izgubivši sve šanse u sukobima s Licinijem, popio je loše komponirani otrov i u mukama umirao. Po Laktanciju, u smrtnom času, ali prekasno, spoznao je Boga. ${ }^{27}$ Dakle, nije kršćanstvo pobijedilo odmah poslije Milanskog edikta; proći će još gotovo jedno stoljeće hrapave kohabitacije s poganstvom. Tek je Teodozije u nekoliko edikata stavio kršćanstvo kao službenu religiju Rimskog Carstva (godine 392.), ali se ni tada čitav rimski narod nije u cijelosti pokrstio. ${ }^{28}$ Stoga, kršćansko kucanje na Dioklecijanova vrata je čista, ali ipak dopuštena fikcija, koju smijemo prihvatiti kao Ogrizovićevu slobodu.

Višekratno sam piscima, koji su se kao umjetnici bavili Dioklecijanom kao književnom temom, pisao i govorio da povijest kao znanost ne trpi široko shvaćenu slobodu bez oslonca na izvore, ali književnost svakako da jer je umjetnost, a umjetnička sloboda je neograničena. Međutim, pisci su najčešće molili za mišljenje jesu li negdje pogriješili. Ogrizović se, očito, postavio slobodno u odnosu na povijesne činjenice, unatoč tomu što je i don Frane Bulić bio uključen. Koliko je ipak Bulić utjecao na Ogrizovića, teško je pretpostavljati. Možda su Bulić i Ogrizović o tome i diskutirali, ali to piscu ovih redaka nije poznato.

Ono što je najkontroverznije u drami jest pojava kćeri i žene koje uvjeravaju ex cara u potrebu da prihvati kršćanstvo. One same, kao što je već rečeno, nisu pouzdano bile kršćanke, ali je zasigurno pouzdano to da one nisu bile nazočne u Splitu neposredno prije careve smrti. One su tada incognito bile u Solunu prateći što će se dogoditi Valerijinom posinku Kandidijanu i ostalim članovima obitelji Severa i Maksimina Daje. Sever je već davno ranije u Ravenni počinio samoubojstvo (puštanje krvi iz žila), a Maksimin se otrovao u Kapadokiji, ali brojni su potomci ostali. Priska i Valerija su se tek tada, nakon 15 mjeseci, mogle vratiti iz svog sirijskog progonstva i kao vrle i plemenite žene željele vidjeti što će se spomenutima dogoditi. Međutim, Licinije, jedan od tvoraca Milanskog edikta, bez kršćanske samilosti ubrzo je sve potomke tetrarhijskih vladara posmicao. Prisku i Valeriju je pogubio odsijecanjem glava, a tijela su im bačene u Solunski zaljev. ${ }^{29}$ Tako nisu dobile ni grob, što je osnovno ljudsko pravo. Dioklecijan je uzalud molio da mu se vrate. ${ }^{30}$ Nije ga uslišao ni Maksimin Daja ni Licinije, a obojicu je uzdigao do vlasti. Ogrizović Prisku i Valeriju vidi u Dioklecijanovoj palači i nagoviješta da će otići Liciniju, zapravo njihovom povijesnom krvniku. Ako bi mi se dopustila kritika navodne pojave Priske i Valerije u Splitu, neka bude

\footnotetext{
${ }^{27}$ Laktancije $D M P$ 50, 5-6.

${ }^{28}$ A. DEMANDT, 2007, 496-498.

${ }^{29}$ Laktancije DMP 50, 1-7, 51.

${ }^{30}$ Laktancije DMP 41, 1-3.
} 
rečeno i da su one i najplošniji likovi u Ogrizovićevu zbivanju, a $\mathrm{k}$ tomu su posve nepotrebne u dramskom zapletu. One su Licinijeve žrtve, ali i žrtve složenih odnosa u carstvu nakon poraza Maksimina Daje. Posrijedi su bili međusobni odnosi Licinija i Konstantina. I Konstantin i Licinije bili su veliki kalkulanti i zvijeri u ljudskoj spodobi koji se nisu kolebali obračunati ni s vlastitom rodbinom, a nekmoli s drugima kad su im stajali na putu.

Ogrizovićeva drama je prije svega sazdana na sukobu poganstva i kršćanstva. Od svih likova najkompleksniji je svakako sâm Dioklecijan koji je dosljedan u svojim protukršćanskim stavovima. Prema Ogrizoviću, to je pitanje caru bilo važnije od svega (pa i od obitelji), što bi možda bilo logično za reformatora koji je uložio svu svoju snagu i znanje da očuva državu u kriznim trenutcima, ali ipak nije bilo tako. Ogrizović doslovno kaže da bi se ex car sa svojim kršćankama obračunao kad ne bi slijedile njegove naputke, a vidjeli smo da je sve načinio da ih vrati sebi, ali nije uspio i zbog toga je od žalosti i umro. Pisac drame je

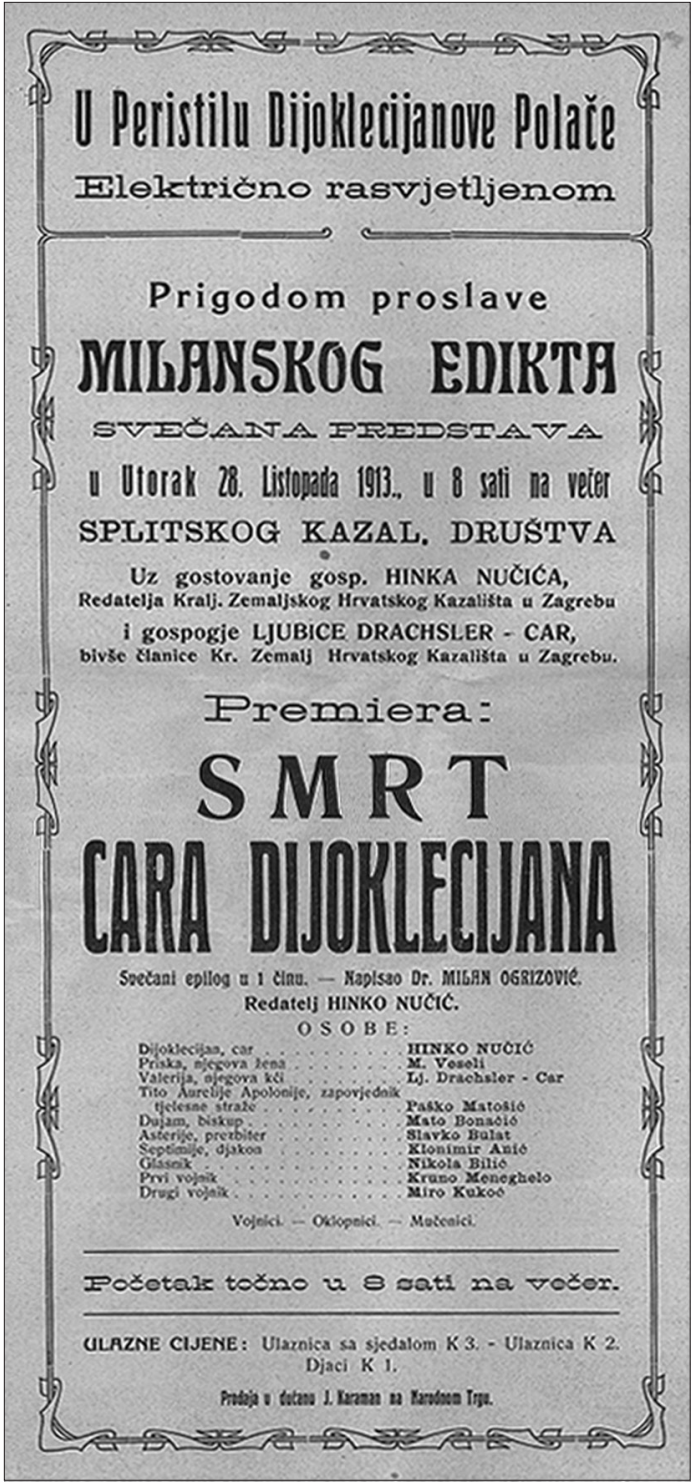

Sl. 3. Plakat tiskan u povodu premijere Smrt cara Dioklecijana, Split, 1913.

(izvor: Muzejska kazališna zbirka HAZU ${ }^{32}$ ) veoma uspješno istaknuo energiju koju je car uložio u borbu s kršćanima. On i sebe žrtvuje i tako postaje vjerodostojan, a ne kukavica, kako ga zlobno opisuje 
Laktancije. ${ }^{31}$ Kršćanska masa od cara traži da odstupi iako je već odstupio, ali on radije odlazi u smrt nego da prekine svoju krutu vjersku politiku. Dioklecijan, naprotiv, zajedno s Galerijem uviđa da je novu vjeru nemoguće iskorijeniti pa prekida progone jer su postali kontraproduktivni. Kao pragmatičnom vladaru, bilo mu je to jasno. Očito je da je trijumf kršćanstva Ogrizoviću dramski u prvom planu, a tomu je kumovala i obljetnica Milanskog edikta.

Bilo je jasno i u trenutku nastajanja dužeg teksta da bi ga integralno bilo teško postaviti na pozornicu. Svjestan toga, Ogrizović je napisao drugu varijantu u kojoj je Dioklecijanov kraj u središtu kao posljedica kršćanske pobjede. Taj dio je izveden na Peristilu, ali poslije nikad više. Danas pak bez velikih dramaturških i režijskih zahvata ne bilo moguće ni pomišljati na postavljanje iako bi za Split Dioklecijanov sukob s kršćanstvom bio zanimljiv jer se upravo u carevom Mauzoleju drastično sukobio, ali skladno spojio carev grob i crkva.

\section{Literatura}

Ivan J. BOŠKOVIĆ, Car na pozornici - Dramska hrestomatija o caru Dioklecijanu, Zagreb, 2012.

Hugo BRANDENBURG, Le prime chiese di Roma IV-VII secolo. L'inizio dell' architettura ecclesiastica occidentale, Milano, 2004.

Frane BULIĆ, Zapažanja o putovanju cara Dioklecijana iz Ravenne u Nikomediju 304. godine, u: Nenad CAMBI (ur.), Frane Bulić, Izabrani spisi, Split, 1984, 71-85.

Frane BULIĆ, Mučenici solinski. Broj stališ, godina i dan smrti mučenika solinskih, u: Nenad CAMBI (ur.), Frane Bulić, Izabrani spisi, Split, 1984, 333-361.

Nenad CAMBI, Dioklecijan: vir prudens, moratus callide et subtilis ili inventor scelerum et machinator omnium malorum. Povijesne kontroverze i današnje dileme, Split, 2016.

John L. CREED, Lactantius, De Mortibus Persecutorum, Oxford, 1984.

Alexander DEMANDT, Die Spätantike. Römische Geschichte von Diocletian bis Justinian 284-565 n. Chr., München, 2007. ${ }^{2}$

Ejnar DYGGVE, History of Salonitan Christianity, Oslo, 1951.

Edward GIBBON, Slabljenje i propast Rimskoga Carstva, sv. 1, Zagreb, 2009. (prijevod Marijan Boršić)

Željko RAPANIĆ, Od carske palače do srednjovjekovne općine, Split, 2007.

VELIKA knjiga svetaca. Ilustrirana enciklopedija po danima, Zagreb, 2011.

${ }^{31}$ Laktancije $D M P 7,2$.

32 OGRIZOVIĆ, MILAN, Književna baština u muzejima, URL: http://kbm.mdc.hr/ knjizevnici/knjizevnik-detalji/milan-ogrizovic/141 (2021-22-8) 


\section{Internetski izvor}

OGRIZOVIĆ, MILAN, Književna baština u muzejima, URL: http://kbm.mdc.hr/ knjizevnici/knjizevnik-detalji/milan-ogrizovic/141 (2021-22-8)

\section{OGRIZOVIĆ'S DIOCLETIAN - REALITY OR FICTION?}

\section{Summary}

Milan Ogrizović was born on $11^{\text {th }}$ February 1877 in Senj. He lived in Zagreb and was the director of the Croatian National Theatre there for a certain period. He was also an eminent Croatian writer. Before the First World War he set on stage the drama about Roman emperor Diocletian who was firstly an ordinary soldier, then a military commander and finally the emperor (Augustus in the dominate period). During his imperial career, he concentrated his skills on the reforms among which he, to the implementation of the tetrarchic system of rule, hoped to stop the crisis in the Roman Empire, in particular the violent changes on the imperial throne by military forces. Diocletian also introduced many other reforms trying to improve social and religious life. Some of them were successful some unsuccessful. One of his badly conceived measures was the persecution of Christians, which resulted in contradictory opinions about his historical role. Despite this, the contradictory attitudes of many outstanding historians and philosophers cherished positive attitudes about his personality and his historical role until modern times. So Edward Gibbon praised his rule: "Like August, we may evaluate him as the founder of a new empire." Diocletian as well as adopted son of Caesar excelled himself more as a statesman, than for his military skill. Theodor Mommsen praised him as the unsurpassed politician. In the focus of the Ogrizović's drama is Diocletian's stubborn persistence on the extermination of Christianity. Diocletian would with others also sacrifice his wife and daughter because of their affiliation to Christianity. But, it is far from being true. The ex-emperor allegedly put aside the relations in his family since he hated Christianity. However, such historical inaccuracy is Ogrizović's artistic freedom.

Milan Ogrizović was the first who performed Diocletian on the stage that was the Peristyle of his Palace in Split. His Peristyle was the place of various real historical events, audiences, protocol and cult festivities where Diocletian appeared and was hailed as imperator senior Augustus. It is the most attractive site for ambient theatre since it was the authentic stage of our days. Since Ogrizović was a theatre man, this fact must have been the inspiration for him. The complete drama was not performed but only the addition "The Death of Diocletian" in 1913, on occasion of the celebration of the $1,600^{\text {th }}$ anniversary of the Edict of Milan staged by the great Croatian and Slovenian actor and director Hinko Nučić. Such an occasion was probably the reason why Ogrizović stressed Diocletian's great hostility towards Christianity that Constantine admitted existed in 313.

Keywords: Milan Ogrizović, play, Emperor Diocletian, Christianity 